\title{
THE AMERICAN COMMITMENT TO PRIVATE INTERNATIONAL POLITICAL COMMUNICATIONS: A VIEW OF FREE EUROPE, INC.
}

\author{
RICHARD C. RowsON*
}

Perhaps a unique event in American history was the founding of Free Europe, Inc, in 1949, unique because this step represented a commitment by the American people to concern themselves with east Europe, to help restore its rightful role as an independent group of nations, part of a larger, increasingly united Europe, and to advance the freedom of its people. It also demonstrated that the American people themselves were determined to do something to express in a practical way this commitment to eastern Europeans and their struggle for national identity and human freedom.

A "Declaration of Policy" set forth in 1950 by the National Committee for a Free Europe, which founded Radio Free Europe, stated:

Action of governments alone is not enough. As American citizens we all share a moral responsibility assumed by our country, as we also share in the dangers. Acting together in such private associations as are appropriate and in consonance with the established views of our government in world and human affairs, we must help to further the cause of liberty and peace. To this end The National Committee for a Free Europe, Inc., is formed.

But from the beginning this commitment to "the cause of liberty and peace" was not undertaken unilaterally but jointly by American citizens and the citizens in exile of Poland, Czechoslovakia, Hungary, Rumania, and Bulgaria. (Also included in the formation of other phases than radio of Free Europe's operations were the citizens in exile of Albania ${ }^{1}$ and the three Baltic nations of Latvia, Lithuania, and Estonia.)

This partnership between the American people and the people of eastern Europe was entered into through a small group of eastern Europeans who had fled from their countries at the time of the communist takeover following the Second World War. These nationals from eastern Europe represented a cross-section of the leadership groups in their former homelands: they were journalists, diplomats, teachers, peasant leaders, former members of parliament, socialists, businessmen, labor leaders, and many were young aspirants to these leadership groups, rather loosely referred to in eastern Europe as the "intelligentsia." These were the people who would have played an active, vital role in their countries had there been established, after 1945, governments based on the consent of the governed.

* B.A. I946, University of California, Berkeley; M.I.A. I950, Columbia University; studied at the Sorbonne, Paris, r949. Director of Policy and Planning, Free Europe, Inc.

${ }^{1}$ From May 1951 to September 1953 Radio Free Europe also broadcasted to Albania. 
Denied the right to raise their voices in dissent and protest against the Sovietimposed communist regimes in their homelands, they had every right, as will be shown later, to speak up and be heard from outside. The American people provided the wherewithal which enabled them to communicate in this fashion with their own countries. A form of "free press" was thereby established under the aegis of Free Europe. The east Europeans provided the "voice"; the Americans took responsibility for the political guidance in close daily consultation with national broadcasters, analysts, and audience experts, for raising the necessary funds from the American public, and for direction of the over-all enterprise, in partnership with Poles, Czechs, Slovaks, Hungarians, Rumanians, and Bulgarians.

What then did this partnership of Americans and east Europeans set out to do? Was it an undertaking in the national interest of the United States and of the east European peoples? Does its mission constitute a proper function for private individuals? Is it sanctioned by internationally accepted moral and legal principles and practices?

It is the purpose of this article to provide answers to these basic questions. But before entering into an exposition of the evidence and arguments, a general statement of purpose is in order. Here is how the President of Free Europe, Inc., Mr. John Richardson, Jr., summarized it for the Committee on Foreign Affairs of the House of Representatives:

I think it is important to recognize that there is nothing wrong or un-American about trying to persuade people abroad to accomplish in their own interest political results which are incidentally of utility to the United States. Nothing could be more American, in my view, than persuasion in the cause of freedom. To promote the dignity of man throughout the world, to enlarge human rights wherever we can, it seems to me, utilizing the peaceful methods of persuasion and truth, is a highly moral effort, which is not only in the political interest of the United States, but is directly based on the ideals on which this country is founded.'

Free Europe and Radio Free Europe

Free Europe and Radio Free Europe-its principal communication arm-are engaged in this "persuasion in the cause of freedom" to serve three interlocking interests:

-first, the interest of east European peoples in achieving national selfdetermination and individual freedom;

-second, the interest of east and west European nations in achieving political stability and economic expansion through a larger unity of Europe as a whole; -and third, the interest of our own country in peace and security, both largely dependent on the progress Europeans make in realizing the first two objectives.

${ }^{3}$ Hearings Before the House Committee on Foreign Affairs on Winning the Cold War: The U.S. Ideological Offensive, 88th Cong., Ist Sess. 599 (1963). 
Thus, the mission of Free Europe is to assist the people in Poland, Czechoslovakia, Hungary, Rumania, and Bulgaria (the five countries to which Radio Free Europe broadcasts), and in Albania and the Baltic countries (the subjects of other Free Europe activities) to achieve what they themselves want: a transformation of their countries by peaceful means into free, self-governing societies able to establish mutual and friendly relationships with all nations in Europe, including the Soviet Union, on a basis which they determine is in their best national interest. The importance of this "program in partnership" undertaken by Americans and east Europeans through Free Europe is demonstrated by the fact that the five nations that comprise Radio Free Europe's audience represent, in the aggregate, an area twice as strong industrially as Communist China and militarily and strategically of great importance to the Soviet Union. Poland, Czechoslovakia, Hungary, Rumania, and Bulgaria constitute, together, the fourth largest industrial complex in the world. They outproduce Communist China in steel, chemicals, and oil five to two, in electric power two to one, and equal her in the production of coal. ${ }^{3}$ Their combined armies are larger than those of West Germany, Britain, and France combined and almost as large as the U.S. Army. ${ }^{4}$

What is the evidence substantiating the fact that the people in eastern Europe do have the kind of commitment to free, self-governing societies that is stated above? A recent survey (one of many similar ones) conducted by western European survey institutes using questionnaires prepared by Radio Free Europe's Audience and Public Opinion Research Department is a case in point. Several hundred Hungarians visiting in the West (more than ninety per cent returned, thereafter, to Hungary) were asked as a part of a more general survey of opinion: "What kind of government would most people in Hungary like to see?" Six per cent answered: "The same as the present, a communist one," but sixty-six per cent called for "a change" either to a national, freely-elected, Western-type government without communist participation (fifty-one per cent), to a "coalition government" (eight per cent), or to a "neutral, socialist, non-communist one" (seven per cent). ${ }^{5}$ Similar results came from interviews of Poles, Rumanians, Czechs, Slovaks, and Bulgarians. ${ }^{\circ}$

But by more than audience research statistics is it possible to "document" this large majority in east Europe who oppose the repressive nature of their present regimes and constitute, thereby, Radio Free Europe's mass audience. As Lewis Galantiere, writing on "The Role of Radio Free Europe" in 1963, put it so eloquently:

\footnotetext{
${ }^{3}$ See Radio Free Europe, Chinese Production Figures Estimated by Soviets 2 (1965); and compate figures in U.N. Monthly Bulletin of Statistics, April 1966, for these countries under appropriate production headings.

'ARMed Forces of the World (Ewing \& Sellers eds. 1966). (Note: Internal security forces are considered an extension of national armies.)

'Radio Free Europe, The Desired Type of Hungarian Government-A Study of Political Hopes OF 3 I 2 RESPONDENTS 3 (I965).

${ }^{6}$ Radio Free Europe, The Effectiveness of Radio Free Europe 26 (1965).
} 
Let me ask you to imagine yourselves behind the Iron Curtain. You live there in a country without freedom of information. All the media are in the hands of a communist government: newspapers, radio, television. All the sources of knowledge are controlled by the government: textbook publishing, libraries, archives, the educational system. So are all the sources of the ideas that move men to defend their interests, assert their rights, demand the political and social organizations they aspire to live under. The care of men's souls is watched; for though the churches are open and are crowded with worshippers, the clergy, once they have celebrated their rites, are free only to advise their flocks, in sermons, to put their trust in God.

Living in such a land, your passionate longing is to hear what is going on outside, in the free world. Your passionate desire is for contact with that world. Your allegiance is to that world. Your detestation is reserved for the men who have cut you off from it-men who govern you, if not everywhere with the visible support of Soviet bayonets, nevertheless as agents of a foreign power.

Given these facts, and given what we know from interviews with those who come out, the answer is: Yes, Radio Free Europe has an audience-a national audience in each of five countries; and one that offers itself, one that doesn't have to be bought.7

How does the Radio act upon this opportunity to bridge the gap between the east European's keen desire for information about the outside world and the denial by his government of that right? The most important method used by Radio Free Europe in this effort is to get the truth to those denied it, to present the news in full and unbiased form and to break, thereby, the present regime's virtual monopoly of information. What is going on in the noncommunist world and within the communist world itself is extensively reported and analyzed. In fact, one of the most effective and telling means of getting a balanced picture of current developments to our audiences is to "cross-report" what is going on in one east European country to the others. Such news and analysis is frequently repressed or distorted by the various communist governments themselves, because of the potential "multiplier effect" those events have within the communist area, if given free play and exposure. In this fashion the Radio reinforces existing trends and pressures for change which slowly are leading to a diffusion of power to individuals and groups outside the small minority of the communist apparat. Thus, does Free Europe serve the function of a "free press" in east Europe, giving voice and expression to responsible views which otherwise would be suppressed by the regimes.

Furthermore, this "voice" speaks a language that the people in east Europe understand, whether they are among the large "mass" audiences, or among the noncooperating elites constituting the so-called "inner emigration," or among the party cadres themselves, especially the dissidents among them who aspire to a greater flexibility and rationality in the interpretation of communist doctrine and practice. This "empathy in communication" is achieved by Poles talking to Poles and Bul-

${ }^{7}$ Galantiere, The Role of Radio Free Eutope, in Propaganda and THE Cold War 85, 88-89 (Whitton ed. $x 963)$. 
garians to Bulgarians, not as a spokesman for some foreign government but as fellow countrymen concerned with the best interests of the country both they and their listeners call home. It is this people-to-people communication that is the principal characteristic distinguishing Radio Free Europe from government media such as the Voice of America or the BBC.

\section{II}

\section{Defintion of International Political Communications}

Before examining the need and international right of political communication across national boundaries and the right to engage in it even if such communication is carried out against the express wishes of any given government, it would perhaps be useful to define what is meant by the phrase "international political communications," which is of course roughly equivalent to the cruder term propaganda. L. John Martin puts it this way: "Propaganda, it has been shown, is a term that is subject to many definitions. The definitions appear to be in agreement about one thing only: that propaganda attempts to influence the thinking of people. There is general agreement that propaganda is aimed at the minds of people, and that the attempt is to direct or strengthen their thinking along predetermined lines." ${ }^{8}$ At another point, Martin summarizes twenty-six different definitions of propaganda as follows: "propaganda is the art of influencing, manipulating, controlling, promoting, changing, inducing, or securing the acceptance of opinions, attitudes, action, or behavior." Perhaps a more precise, working definition is given by Paul M. A. Linebarger: "Propaganda consists of the planned use of any form of public or mass-produced communication designed to affect the mind and emotion of a given group for a specific public purpose whether military, economic or political."10 Thus, the term, "international political communications," as it is used in this article, consists of (a) public communication directed to a mass audience $(b)$ whose use is planned ( $c$ ) to affect the minds and emotions $(d)$ of groups and not just single individuals $(e)$ for a specific public purpose.

Looked at in these terms, international political communications does not have a pejorative meaning but, rather, becomes a term describing a legitimate means of communication which, as long as it is based on fact, does not attempt to distort the truth, and operates within international legal norms, is an accepted practice of international relations, as will be discussed next.

III

\section{The Need for International Political Communications}

Nobody doubts any more that a battle is going on for the minds of men, nor that at stake are the freedoms of people everywhere as well as the security of this

\footnotetext{
${ }^{8}$ L. John Martin, International Propaganda igg (1958).

${ }^{\circ}$ Id. at ro.

${ }^{10}$ PaUl M. A. Linebarger, Psychologicat Warfare 39 (I948).
} 
nation. Private citizens in this country and elsewhere have a role in this struggle and a commitment to it. Free Europe and its principal arm, Radio Free Europe, interpret this commitment, this need for international political communications, in both moral and political-strategic terms. The political and strategic importance of eastern Europe has already been described above in a comparison of this area's power with that of Communist China. The application of these factors to the present-day European situation and to the Soviet Union's political and strategic designs in Europe is best done by evaluating the situation in relation to Berlin and Germany.

Over the past twenty years it has been the Soviet aim to drive the allies out of Berlin and threaten all of Germany from East Germany. This strategy is designed to end all hope on the part of the east Europeans for genuine independence and to reduce them to a "docile" area subject to Soviet control and influence. If this had been achieved, presumably it would have been possible for the Soviets to carry their influence all the way to the Atlantic, utilizing the support of friendly west European communist parties and governments they might influence or control.

Thus, eastern Europe, looked at in this perspective, constitutes an area of key importance to the Soviets and to those in the West concerned with over-all European security and resistance to Soviet domination in Europe. The possibility of realizing a voluntary reassociation of east and west Europe on terms acceptable to all European nations is enhanced by progress toward freedom and independence in eastern Europe. Any such progress forces the Soviets to acquiesce, increasingly, in such a reassociation (in which she herself might eventually take part), based as it would be on close ties from the past and common cultural traditions.

Furthermore, since this kind of European security is basic to American and Atlantic security, the eastern European area becomes of great strategic interest to the United States as well as to western Europe. It is, therefore, important that all means, including international political communications, be used by the West to prevent the exploitation of this strategic eastern European area and her peoples by the Soviets for the advancement of Soviet policy designs.

Another way to put this argument is to state that the military, diplomatic and economic arms of statecraft have been joined in the twentieth century by what Professor John B. Whitton has called the "fourth arm of statecraft," namely, psychological persuasion through communications. ${ }^{11}$ The Soviets, the Communist Chinese, and other powers are engaged fully in this strategic and psychological struggle using the "fourth arm of statecraft" to the extent of their own capabilities and resources; it follows that the West, and specifically the United States, must exercise vigorous leadership, imagination, and commitment in this same area in order to compete, in order to protect western national interests and advance freedom and national independence.

\footnotetext{
11 Foreword to Propaganda and the Cold War at iii (Whitton ed. 1963).
} 
But in addition to these political and strategic necessities for international persuasion, the activities of Free Europe satisfy a moral need as well. Over the past twenty years, hundreds of millions of people in Asia and Africa have emerged from the bondage of colonialism and have regained independence. During this same period, control by the Soviet Union over the destinies of the east Europeans has been imposed upon these peoples either directly or through others in close association with Soviet interests, namely, the communist parties of eastern Europe. The right of roo million people to a determination of their own affairs based upon a free expression of individual and collective will has been denied at a time when on other continents, other peoples have achieved this right. Any use of force to initiate "liberation" of the people in this area is ruled out both on moral and practical grounds. An attempt to achieve national and individual freedom through negotiation is unforeseeable, given the present realities of power politics in eastern Europe. A reliable way to penetrate and influence development there is through the media of international political communications. If the people in this area are denied, by their own governments, their moral right to know what is going on inside eastern Europe as well as in the rest of Europe and the world outside, it becomes the right and obligation of their exiled countrymen and others who believe in the universality of their rights and freedoms to help them overcome this denial of freedom to know.

\section{IV}

\section{Effective International Political Communications}

George Gallup has contended that there is no point in spending millions of dollars on persuasion (even to reach an audience as large as Radio Free Europe's over twentytwo million regular listeners) unless it is certain that results are being achieved. He points out that the key to such results is "to find out which of many basic appeals should be incorporated into our propaganda program and to measure the effect of these ideas in changing attitudes."12 Radio Free Europe devotes considerable effort to this kind of audience and public opinion research. In 1965 , over 5,000 interviews conducted by west European public opinion institutes using RFE-prepared questionnaires were analyzed, as well as over 13,000 letters received from listeners. As mentioned earlier, ninety per cent of those interviewed were travellers from eastern Europe who were returning to east Europe. Thus, if there is a bias in these results it is weighted against RFE.

These are some typical findings: (I) News is the most popular RFE program. (2) Political commentaries rate second. (3) East European audiences listen most to their own government radios for entertainment and not for news, commentaries, or

\footnotetext{
${ }^{12}$ Gallup, The Challenge of Ideological Warfare, in Propaganda AND the Cold War 54, 56 (Whitton ed. $x_{96}$ ).
} 
other political-type programs. (4) Regular listenership to RFE exceeds twenty-two million and represents forty to sixty per cent of the total potential listening audience. ${ }^{13}$

But perhaps the most important kind of opinion research conducted by RFE concerns attitude changes. Following considerable broadcasting by RFE of the Sino-Soviet split throughout 1963 and 1964 , RFE's Audience Research and Public Opinion Department, in cooperation with west European polling institutes, tested east Europeans' opinions on the "Great Schism." While in 1963 an average of forty per cent of the respondents from all the east European countries took the Russian side in this controversy, the ratio of support in Ig64 was considerably narrowed to 28.I per cent. At the same time an average of more than six out of ten respondents (sixty-one percent) refused to identify with either side. ${ }^{14}$

What is the significance of this development? Our survey findings indicate that this can be interpreted as a definite shift from limited pro-Soviet involvement to an increased tendency toward disengagement by the bulk of the area population, i.e., fewer people took sides in the conflict. On the other hand, our findings indicate that there exists an increased interest in the conflict per se with a view to exploiting it for national interests. RFE's position, that the conflict could be exploited to gain a greater measure of national independence and internal liberalization, seems to have been widely accepted. ${ }^{15}$

Perhaps the most important manner by which Free Europe finds out which of many basic appeals should be incorporated into our programs and measures the effect of these in changing attitudes is our extensive research and analysis effort. To keep abreast of communist affairs and propaganda lines, RFE daily monitors the radio broadcasts and news agency transmissions of twelve communist countries. This material, plus more than 700 communist newspapers and other publications which are read and evaluated each month, enable RFE to keep its finger on the pulse of life in each of the east European countries to which we broadcast and to supply information denied east Europeans by their governments. RFE staff experts on east Europe, the Soviet Union, and Communist China and all phases of world affairs furnish programmers with a sound basis for reliable, perceptive political commentary. As testimony to the reliability of this research and analysis and the unique service RFE performs as the largest center for this kind of research anywhere in the world, more than 700 scholars, journalists, and government experts from the United States and Europe subscribe to RFE's research papers. Hundreds more visit Munich and use RFE's research materials there each year. ${ }^{16}$

\footnotetext{
${ }^{13}$ Radio Free Europe, The Effectiveness of Radio Free Europe II, 14 (I965).

It Id, at 22.

${ }^{16} I d$. at 23 .

${ }^{10}$ Free Europe Commitsee, Inc., The Job Ahead 9 (1965).
} 
International Law and International Political Communications

Let us now turn to an examination of the question of whether there is any legal basis in international law for international communications of the type carried on by Free Europe. The conclusion one quickly reaches on this point is that it is not possible to state an explicit legal right under international law for this kind of communication. However, it is possible to state that it is a "general principle accepted by civilized nations" (one of the five principal sources of international law) that there is a right to receive information and ideas across national frontiers.

For example, article I9 of the Universal Declaration of Human Rights, adopted by the General Assembly of the United Nations, December 10, I948, states, "Everyone has the right to freedom of opinion and expression; this right includes freedom to hold opinions without interference and to seek, receive and impart information and ideas through any media and regardless of frontiers."17 This Declaration, however, is no more than a recommendation. The Brussels Pact in 1948, the Consultative Assembly of the Council of Europe in 1949, and the Convention for the Protection of Human Rights and Fundamental Freedoms of the Council of Europe in $195^{\circ}$ adopted similar proposals. ${ }^{18}$

From an exhaustive search of international legal precedents, it is clear that the kind of international communication authorized in these various declarations, i.e., persuasion "across national frontiers" with or without the consent of the government of the recipient country, does not violate international law so long as it complies with the United Nations Charter: "All Members shall refrain in their international relations from the threat or use of force against the territorial integrity or political independence of any state, or in any other manner inconsistent with the Purposes of the United Nations."19

What some authors have interpreted this to mean, in practice, is that so long as international persuasion is not "subversive, warmongering or defamatory" it is not contrary to international law. ${ }^{20}$ Others maintain that the words of this section of the U.N. Charter should be interpreted as meaning that all international communication is permissible so long as it does not constitute a "threat or use of force" by one state against the territorial integrity or political independence of another state and is not an action inconsistent with the "Purposes of the United Nations."21

\footnotetext{
${ }^{17}$ U.N. Dep't of Public Information, These Rights and Freedoms 173 (U.N. Pub. Sales No. I950.1.6).

${ }^{18}$ Martin, op. cit. supra note 8 , at 97 .

${ }^{10}$ U.N. Charter art. 2, para. 4.

20 John B. Whitton \& Arthur Larson, Propaganda: Towards Disarmament in the War of Words 179-80 (I964) [hereinafter cited as WhItTON \& LARson].

${ }^{21}$ MARTIN, op. cit. supra note 8, at 7r, 107-08.
} 


\section{VI}

\section{The Moral Right of International Polittcal Communicattons}

It is necessary to turn to the area of "moral right" to find a positive justification for international political communications. If there is no legal right to engage in such communications across national frontiers (nor any legal prohibition, either), there is a strong moral "right to know," a right to have access to unbiased information and to express and to receive opinions freely. ${ }^{22}$ The denial of this right by the communist regimes of eastern Europe is the primary basis for Radio Free Europe's moral right to broadcast to the people who live in these countries.

This broadcasting is based upon several assumptions, in addition to the evidence cited earlier demonstrating RFE's popular appeal among the peoples of eastern Europe. These assumptions are the following:

First: An informed public is preferable to an uninformed or ill-informed one. This argument assumes that a government, subject to the pressures of public opinion, is far more apt to be peace-loving than one controlled by a small group of leaders who exercise totalitarian control over the people and the government and over the decisions of war or peace.

Second: (And this is more than an assumption.) It can be documented by intensive and extensive audience research studies among east Europeans, that they are opposed to the denial of their essential liberties and that they desire or demand, as the case may be, reforms which alter, relax, and eventually will eliminate these restrictions.

Third: As the communist regimes represent, according to their own pronouncements, institutionalized hostility to those who do not accept their doctrines, it is necessary for those who believe in the principles upon which diverse and free societies are based to resist all attempts by nations subscribing to Marxist-Leninist principles to undermine free systems and take away the freedoms on which these systems are based.

To document this last point and the fact that Lenin's own doctrines of international revolution have been updated and reaffirmed by more recent communist leaders, one need only quote from the Statement of Eighty-one Communist and Workers' Parties adopted at Moscow in I960:

Co-existence of states with different social systems is a form of class struggle between socialism (communism) and capitalism. In the conditions of peaceful co-existence favorable possibilities are created for developing the class struggle in the capitalist countries and the national liberation movement among the peoples of the colonial and dependent countries.... Peaceful co-existence of states with different social systems does not mean reconciliation of socialist and bourgeois ideologies.

${ }^{22}$ Id. at 97. 
On the contrary, it assumes intensification of the struggle by the working class and of all the Communist Parties for the triumph of socialist ideas. ${ }^{23}$

Stripped of its ideological semantics, this passage simply means that communists should regard "peaceful coexistence" as an opportunity for agitation, infiltration, and other activities designed to promote unrest and hasten the creation of revolutionary situations.

A further example of this threat to the existence of "freedom in diversity" and of the need to resist this threat with the international dissemination of fact and analysis is seen in the Soviet Union's disregard for the U.N. Charter's clause on nonintervention as well as its disregard for many of its own subscriptions to this stand-most recently, its own resolution passed by the United Nations concerning the principle of nonintervention. $^{24}$ At the recent Havana Tri-Continental Conference, the Soviet Union's delegate voted for resolutions supporting the so-called "national liberation movement," with particular reference to the Dominican Republic, Guatemala, Venezuela, Colombia, and Peru. A committee organized to further this end has the Soviet Union as a member. ${ }^{25}$

On February 2, the Organization of American States condemned the U.S.S.R. and other participants in the Havana Conference in a 18-0 vote, with Mexico and Chile abstaining on legal grounds. ${ }^{20}$ All Latin American neighbor and sister republics of Cuba, with the sole exception of Mexico, charged that the conclusions of the Havana Conference constituted the first violation of the U.N. General Assembly declaration, initiated and supported by the Soviet Union, as stated above. ${ }^{27}$ The U.N. resolution said in part: "Also, no state shall organize, assist, foment, finance, incite or tolerate subversive, terrorist, or armed activities directed toward the violent overthrow of the regime of another state, or interfere in civil strife in another state."28 The Organization of American States' resolution stated, in part:

The proclamation adopted by the conference [at Havana] on the use of force as one of the principal means for attaining its objectives, and the establishment of a permanent machinery to this end, struck at the fundamental principals of international law as stipulated in the Charter of the United Nations and the provisions of the above-mentioned declaration of the General Assembly on the inadmissability of intervention in the domestic affairs of states and the protection of their independence and sovereignty. ${ }^{29}$

\footnotetext{
${ }^{23}$ Current Digest of the Soviet Press, Dec. 28, r960, p. 9.

24 U.N. Gen. Ass. Off. Rec. 20th Sess., Resolution Adopted by the General Assembly, No. $213 \mathrm{X}$ (XX), Dec. 2r, 1965, agenda item I07, Jan. II, 1966.

${ }^{25}$ Fortuny, Delgado \& Salibi, The Tri-Continental Conference, World Marxist Review, March 1966,

${ }^{20}$ The OAS in Action, The Americas, Feb. 1966, p. 42.

${ }^{27}$ Ibid.

${ }^{28}$ U.N. Gen. Ass. OfF. Rec. 2oth Sess., op. cit. supra note 24 , at 3.

29 U.N. Security Council OFF. Rec. (Letter of Feb. 7, I966, to the Chairman of the Sccurity Council, signed by 18 Latin-American countries of OAS, p. 1 , para. 4) (S/7I23) (1966).
} p. 24 . 
Thus the historical institutionalized hostility of communism to those who do not accept Marxist-Leninist doctrines has been brought up to date and reconfirmed.

In summary, the "right" of international political communications as seen by Free Europe is not only based on the moral right of people anywhere to have access to full and complete information and to the free expression of differing viewpoints; it is also based on the overt hostility of communist parties in the Soviet Union and in eastern Europe to these internationally accepted principles of free speech and the "right to know" and to the principles of international law denying the right of one state to intervene in the domestic affairs of another in contravention of national independence and sovereignty.

This right to international communications of all kinds to any people anywhere who are denied full information should extend not only to the area of radio communications but also to the dissemination of books and magazines, to the exchange of persons, ideas, and all matter of informational materials, and to all kinds of international projects which render "assistance in kind" from one nation or group of people to another, such as the recently dedicated American Research Hospital for Children in Poland, constructed with United States donated funds.

Those who deny this right to international communications and persuasion are holding to an archaic attitude which has, throughout the course of history, stood against free exchange of information and opinion. Thus, because of a fear of "contaminating" or "foreign" beliefs or influences, the Italian city-states and pre-Perry Japan, both attempted, unsuccessfully, to deny their own people contact with the world outside their own provincial borders.

\section{VII}

\section{Internattonal Norms and Political Communications}

In exercising this right of international persuasion, Free Europe accepts and abides by those norms and standards of international practice guiding such communication. Basic, however, to our adherence to these international norms is Free Europe's primary respect for the right to freedom of information. As Professors Whitton and Larson put it in their book:

Since 1945 collective efforts of remarkably wide scope and intensity in the field of freedom of information have been made continuously by a number of United Nations agencies. The post-war movement was given considerable impetus by President Roosevelt's Four Freedoms Speech during the war, and at San Francisco, largely due to pressure from the United States, the cause of freedom of information was consecrated in the United Nations Charter as one of the human rights and fundamental freedoms..$^{30}$

Professors Whitton and Larson lay stress on the dual nature of the problem facing the international communicator-the obligation to respect international norms in all

\footnotetext{
${ }^{30}$ WhitTon \& LARSON I95.
} 
operations while also recognizing the obligation to respect the right to freedom of information:

[T]here are two parallel duties to be performed by any effort in the field of international communication. The one function is to minimize damaging propaganda. The other function is to maximize freedom of communication. The two functions are closely interrelated, and the one cannot be considered apart from the other. For example, inevitably when controls on harmful propaganda are being considered, a point is reached at which it must be asked whether the gains to be achieved through suppression of damaging propaganda are overbalanced by the losses that ensue in the form of undue restraints on free communication between peoples. So also ... the more freedom of information can be achieved, the more difficult it will be for distorted propaganda to survive the competition of truth." 31

This is precisely as Free Europe sees the situation and attempts to interpret it dayby-day, in connection with our own operations.

What are these internationally accepted norms which guide the operations of those engaged in international communications? As referred to earlier, ${ }^{32}$ Professors Whitton and Larson define these norms under three headings prohibiting ( $\mathrm{I}$ ) warmongering, (2) subversive, and (3) defamatory propaganda. While accepting as part of its operating practices these internationally accepted restrictions against the use of persuasion which is subversive, warmongering, or defamatory, as illustrated by the broadcasting guidances quoted in part below, Free Europe believes that the only legal norm placed upon international propagandists, private or state controlled, is the provision in the U.N. Charter requiring states to refrain from "the threat or use of force against the territorial integrity or political independence of any state."33 Thus Free Europe abides by the injunctions outlined by Professors Whitton and Larson against subversive, warmongering, and defamatory propaganda without making a judgment as to their binding legal nature under international law.

The best testimony to this is the following set of standing policy guidances for Radio Free Europe, which regulate daily RFE broadcasting operations:

I. Avoidance of broadcast materials the content or tone of which is or could be legitimately construed as inflammatory.

2. Avoidance of any action which would amount to or could be legitimately construed to be incitement to uprising.

3. No programs should be broadcast which are based upon or use rumors or unsubstantiated information.

4. Radio Free Europe should not lead the people to believe that in the event of an uprising the West would intervene militarily.

5. Criticism of the regime should be to the fact and to the issues involved.

${ }^{81}$ Ibid.

${ }^{32}$ See p. 466 supra.

${ }^{33}$ U.N. Charter art. 2, para. 4. 
6. Radio Free Europe should not broadcast any material which would be characterized as petty gossip, slander or attack on the personal lives or families of regime figures or of individuals as such.

In short, Radio Free Europe exercises every possible precaution to insure that all its broadcasts are based upon fact and objective analysis; the choice as to what action should be taken on the basis of these facts and analyses is left to the listener to decide for himself-the Radio does not prescribe or proscribe a given course of action. When suggestions are made presenting alternative courses of action, these are carefully and judiciously supported by extensive background information and analysis, and any element of "incitement" to action is scrupulously avoided.

Thus, Radio Free Europe cannot be compared in any manner, shape, or form with the kind of international propaganda which often characterizes the broadcasts emanating from Castro's Radio Havana or from Nasser's Radio Cairo, from Communist China's Radio Peking or from Radio Moscow, which frequently issue direct calls to revolt, or recommend direct action against the leaders of particular countries, even including, in some instances, calls for the assassination of particular leaders, and which generally attempt to persuade or encourage the listeners in the "target areas" to take subversive or violent action to bring about a change in the status quo.

There is another international norm which is generally respected in the West but which is used in the attempt, largely unsuccessful, to impede the effective and rightful operation of Free Europe by some of the east European regimes. This is the international principle against the jamming of foreign radio broadcasts. Such jamming is still directed against Radio Free Europe's broadcasts to Czechoslovakia and Bulgaria and, to a limited extent from outside the country, against Radio Free Europe's broadcasts to Poland. ${ }^{34}$ Jamming, as any other prohibitive action against the free flow of information or ideas (restrictions on the circulation of newspapers, magazines, and books, the various prohibitions placed upon foreign travel, and so forth), so long as these international persuasion efforts are conducted within acceptable international practice, is not sanctioned by international law. At the May 1950 meeting of the United Nations Sub-Commission on Freedom of Information and of the Press in Montevideo, "an important resolution was adopted (8-3) condemning the jamming of radio broadcasts as a violation of the accepted principles of freedom of information."35 Furthermore, "The General Assembly on December I4, I950, by a vote of 49-5, adopted a resolution condemning jamming as a violation of the accepted principles of freedom of information and as a denial of the right of all persons to be fully informed."36 However, these statements are recommendations only.

\footnotetext{
84 Free Europe Comatrtee, Inc., Bridges to East Europe 8 (1964).

${ }^{36}$ WhITTON \& LARSON 204.

${ }^{80}$ Id. at $2 \mathrm{rI}$.
} 


\section{Conclusion}

At no time in history has the technology of communication promised so much benefit to so many people throughout the world. For example, it is now possible to look forward to facsimile or electronically transmitted newspapers which can be sent directly to a home television screen by satellite and reproduced in "newspaper" form directly into the hands of the reader. Or a book in the New York Public Library will be able to be requested in London, located in New York, and transmitted electronically by satellite to the requesting party in London. Home "dish" antennas will be able to pick up television or FM radio broadcasts from satellites, directly, without the aid of ground-relay facilities.

All of these technological advances, foreseeable and probably available to the general public in many countries within ten years, make technically possible a full realization for nearly all people of the fundamental human rights of freedom of information and freedom to hear all available viewpoints on any given issue. What a tragedy it would be for mankind if this practical possibility of universally free expression and of fulfilment of the right to know were denied by those fearing its consequences or misused by a failure to observe accepted practices guiding international communications. This unparalleled opportunity to expand international understanding, individual freedom, national independence, and international cooperation must not be lost to short-sighted ideological preoccupations or other repressive measures.

At a recent White House conference celebrating "International Cooperation Year," it was proposed that a "Voice of Peace" be established under the aegis of the United Nations to enable individuals, private groups, or nations to avail themselves of the rich resources of the world's knowledge in order to help solve national problems, undertake new enterprises, develop an entire economy, or merely be informed on current events anywhere in the world. Free Europe heartily endorses this proposal as holding out prospects for a new era in "international political communications" in the best sense of that term. In this fashion international communications and the international community which it serves could become the servant and not the master of mankind. 